\title{
THE LARGE MAMMALS OF THE KRUGER NATIONAL PARK - THEIR DISTRIBUTION AND PRESENT-DAY STATUS
}

\author{
By U. DE V. PIENAAR, Ph.D. \\ (Biologist, Skukuza, Kruger National Park)
}

\section{INTRODUCTION}

The Kruger National Park, one of the largest and the oldest in the Southern hemisphere occupies a vast area of some 7,340 square miles in the extreme north-east of the Transvaal Lowveld between $22^{\circ} 25^{\prime}$ to $25^{\circ} 32^{\prime}$ latitude south and between $30^{\circ} 50^{\prime}$ to $32^{\circ} 2^{\prime}$ longitude east.

The eastern boundary of the Park follows the Lebombo mountain ridge on the border between Transvaal and Mocambique, which is an important faunal barrier, separating to a greater or lesser extent the true tropical fauna of the Mocambique plains from the transitional fauna of the Eastern Transvaal Lowveld. The northern and southern boundaries are also natural i.e. the perennial Levubu and Crocodile Rivers, which act as less specific faunal barriers. The western boundary of the Park is for the most part artificial and had, at the time of proclamation, unfortunately not been demarcated with the object of creating an ecologically self-sufficient game sanctuary. It follows a more or less arbitrary line from south to north, has been subjected to considerable changes during the history of the Park and was finally entailed during 1960-1961 by a substantial barbed-wire game fence along the whole of its some 300 miles meandering course.

A portion of the eastern boundary as well as the northern and southern boundaries are also fenced, but being natural delimitations the fence here has a much less important bearing on the well-being and survival of the inhabitants of the Park than that along the western boundary, which cuts through established game habitats, excises important seasonal grazing grounds east of the Drakensberg escarpment and deprives migrating game of traditional watering points during the dry season or drought conditions. The fencing of the western boundary of the Park which had nevertheless become an urgent necessity because of agricultural and poaching pressure on the boundary has brought about the realization more than any other single factor that the Kruger Park despite its extensive area, is incapable of supporting and maintaining a large inherent game population without artifi- 
cial aid in the form of a network of boreholes and dams and a policy of scientific veld management.

It is therefore safe to maintain that the Park would have attained the saiuration point of its carrying capacity with respect to its ungulate fauna long ago had it not been for the provision of an ever increasing number of artificial watering points away from the perennial rivers and permanent natural waterholes through the years. Even today the most important limiting factor which stifles the population growth of many species in the Park is a lack of sufficient water supplies in their chosen habitats.

A carefully-planned program of purveyance of drinking facilities where such is still lacking will be continued with for quite a few years to come, always bearing in mind the dangers of overstocking and the importance of grczing areas which are only accessible to the game during the summer monihs. Had such a program not been embarked upon many years ago, there is little doubt that many species would today have been in danger of extinction and the ungulate community numerically much weaker than it is at present.

The lack or abundance of water in game habitats in the Park could be regarded as one of the most important factors governing the decline or growth of a particular population through the years. It is true for instance, that the actual carrying capacity of the northern mopaniveld with respect to elephants is enormous, but the limiting factor had always been a lack of water away from the perennial rivers, and was the causative factor instrumental in the southward migration of elephants from the original nucleus herds in the north since 1939. Other populations were again profoundly affected by changes or deterioration of the habitat, competition with more adaptable species, specific environmental affinities, selective grazing habits, severe droughts, parasitic diseases and epizootics, or in isolated instances by the excessive depredation by carnivores, thereby causing seasonal or protracted fluctuations in the growih curve of these populations. With the exception of black rhinoceros and oribi, both of which became extinct after the proclamation of the old Sabi Game reserve in 1898, and eland and tsessebe which disappeared from the southern district of the Park, all other populations have shown an undulating but inclining growth curve over the years. After the appalling slaughter of game perpetrated by indigenous Bantu tribes and pioneer white hunters during the last half of the 19th century and the heavy toll claimed by the great rinderpest epizootic of 1897-98, the Lowveld at the turn of the century carried but a pitiful remnant of ihe great herds of game of bygone years.

In 1912 the late Warden of the Park, Col. Stevenson-Hamilton, estimated the number of herbivores in the old Sabi Game reserve, which included a large tract of country between the Crocodile and Olifants Rivers outside the present western boundary as roughly 30,000. In 1925 the same author considered that the Sabi Game reserve contained no less than 100,000 head of 
game and the Shingwedzi reserve a further 30,000. Despite a series of bad drought periods after the proclamation of the Kruger National Park in 1926, which caused temporary declines in the growth curves of many ungulate populations, the inhabitants of this unique sanctuary have reacted so favourably to the extensive improvement in game management schemes of recent years that the overall population figure have now well exceeded the 250,000 mark, and is still rising steadily in the case of the large majority of species. In some instances the increase in numbers over the last few years have been unprecedented and has been precipitated by various factors such as the western boundary fence, an adequate firebreak and veld-management system, the combat of epidemic diseases, and better distribution of watering poinis, so much so that this phenomenon is viewed with some concern in certain areas where there are already unmistakable signs of overstocking. In such areas there has already been embarked on a programme aimed at the diminution by artificial means (mass translocation) of game numbers in order to restore the natural balance. In the case of large animals such as elephant, hippopotamus, giraffe and even buffalo - all species with few or no natural predators, cropping or control of superfluous numbers will probably have to be considered within the not too distant future.

A species which became extinct before the proclamation of the old Sabi reserve - white rhinoceros, has been reintroduced into the southern section of the Park from the Umfolozi game reserve in Natal during 1961. Oribi were reintroduced during 1962 and the only species of large mammal still missing from its grazing grounds of yore in these parts is the black rhinoceros. A concerted effort will be made during the next few years to re-establish these rare beasts in their old haunts in the Kruger Park; thus making up the full complement of herbivorous species which existed in the Eastern Transvaal Lowveld within historical times.

Topographically the Kruger National Park presents an undulating aspect, although it appears rather flat generally. The highest altitudes are attained in the south-west $(2750 \mathrm{ft}$. above sea level) and the country declines towards the Lebombo flats on the east, which are only 600-800 ft. above sea level. The Lebombo mountain range on the eastern boundary reaches its highest level at Shilowa poort in the norih (1628 ft.). The Park is traversed from west to east by 5 perennial rivers, and drained by numerous dongas, dry water courses and seasonal rivers. The Olifants and Sabi Rivers divide the Park into three regions, which for administrative reasons are referred to as the northern, central and southern districts respectively. The rolling landscape is interrupted at frequent intervals by small rocky outcrops or koppies so typical of the Eastern Transvaal bushveld, and which consist of weather-resistant rock belonging to the Swaziland system, archaic granite or dolerite. There are no high mountain ranges in the Park, but the Lebombo ridge on the eastern boundary, the Malelane area and the country north of Punda Milia may be described as mountainous, 
The mean annual rainfall varies from 27.8 inches around Pretoriuskop in the souih-west to 15.67 inches in the extreme north-east at Pafuri. Precipitation is mainly encountered in the form of thundershowers during the summer months.

The $18^{\circ} \mathrm{C}$ mid-winter surface isothermal line which separates the tropical Mocambique plains from the climatically transitional Transvaal Lowveld follows for the greater part the Lebombo ridge in the south but cuts across to the west for some distance in the region of Olifants Gorge and again north of Shingwedzi River towards the Levubu-Motale junction. (Poynton, 1960).

Van der Schijff (1958) classified the vegetation of the Kruger National Park into the following six major veld types:

(i) Large-leafed deciduous woodland with tall grass.

(ii) Mixed Combretum veld.

(iii) Knobthorn - Marula parkland.

(iv) Communities of dolerite dykes.

(v) Mopani woodland.

(vi) The sandveld communities of Punda Milia and Nwambia.

In any treatise of the present-day status of the large mammals of the Kruger National Park and discussion of their distributional pattern, it is essential to consider such in the light of their respective environmental affinities and choice of habitat. Although the vegetation of the Park may therefore be arbitrarily sub-divided into six plant-communities or biomes in respect of dominant species, it is well to remember that each major veld-type encompasses a number of well defined areas of diverse vegetational and topographical aspect. Individually or in toto these areas afford sanctuary and provide in the ecological affinities of competing or co-existant large mammal species which occupy similar or different ecological niches.

An attempt has been made in fig. (i) to distinguish between the more important and distinctive game habitats differentiated from the vegetational milieu of the Kruger National Park. It is considered that an appreciation of the habitat preferences of the large mammal species in the Park may elucidate to some extent the overall distribution range and pattern of such species in Africa.

\section{THE GAME HABITATS IN THE KRUGER NATIONAL PARK}

The following brief description serves to indicate the ecological differentiation of the major game habitats in the Kruger National Park.

(i) The Nyandu bush.

This game habitat covers an area of some 70 square miles in the far north-east of the Park and is essentially similar in character to the 'Matheshi bush' and Cryptosepalum forests of the loose sands in Barotseland and parts of Northern Rhodesia (Fraser Darling, 1960). It is found on deep loose red sands of a Kalahari-like origin and is a spur of the vast sand-veld region 
which covers most of the area between the Limpopo and Olifants Rivers in Portuguese East Africa. It is intensely sensitive to fire and inclined to extensive coppice growth after damage by fire. In certain areas these thickets are so dense as to preclude completely any grass growth. The tree and shrub flora is largely deciduous and the dominant species is Baphia obovata. Associated species of particular botanical significance are Xylia africana, Ostryoderris stuhlmanni, Hugonia swynnertoni, Xylotheca kraussiana var. kraussiana, Guibourtia conjugata and Clerodendrum pleiosciadium - all representatives of the tropical flora of the Mocambique plains which are more or less restricted in their range and which confer a unique status to this area in the Republic of South Africa.

Other trees and shrubs commonly found in this plant community include Ptaeroxylon obliquum, Leptactinia benguellensis, Monodora junodii, Combretum celastroides, Afzelia cuanzensis, Spirostachys africana, Pteleopsis myrtifolia, Balanites maughamii, Dalbergia nitidula and Dalbergia melanoxylon, Strychnos decussata, Croton steenkampiana, and Euphorbia ingens.

There are no water-courses or rivers draining this area - water being conserved only in a series of semi-permanent pans (after the wet season) which all contain a dense growth of the floating water grass Paspalidium platyrachis. The dominant species making up the discontinuous grass cover are Digitaria spp., Eragrostis spp., Aristida uniplumis var. neesii and Urochloa rhodesiensis, with Panicum maximum, Tricholaena monachne and Perotis patens less prominent.

The Nyandu bush is the exclusive habitat in the Park of Livingstone's suni, a typical inhabitant of the Mocambique plains and also of the Mocambique golden mole (Amblysomus (Chrysotricha) obtusirostris limpopoensis) and several lower vertebrate species. Spring hares are plentiful here and the resident ungulate fauna include buffalo, sable antelope, kudu, nyala, zebra, eland, roan antelope (rarely), steenbuck, Sharpe's steenbuck, grey duiker as well as elephants.

(ii) Light Montane forest and overgrown valleys.

A relatively open forest vegetation of evergreen and deciduous species wih several strata, which covers the slopes of Numbi hill and most of the mountainous country north-west of Malelane and Punda Milia. In the Punda Milia area the sandy substratum is derived from the Dominion reef system. The tree stratum here is represented amongst others by Burkea africana, Albizia versicolor, Anthocleista grandiflora, Adina microcephala var. galpinii, Albizia adianthifolia, Diospyros mespiliformis, Albizia amara subsp. sericocephala, Combretum mechowianum, Pterocarpus angolensis, Xylopia odoratissima, Tabernaemontana elegans, Markhamia acuminata, Afzelia cuanzensis, Acacia polyacantha subsp. campylacantha, Pteleopsis myrtifolia, Guibourtia conjugata, Ficus spp., Phyllogeiton discolor, Lonchocarpus capassa, Pseudolachnostylis maprouneaefolia, Drypetes gerrardii, Commiphora marlothii and 
Crossopteryx febrifuga. Important species in the shrub-stratum include Diplorrhynchus condylocarpus, Rothmannia fischeri, Cordia grandicalyx, Holarrhena febrifuga, Hymenocardia ulmoides, Heeria paniculosa, Artabotrys brachypetalus, Landolphia kirkii, Bauhinia galpinii, Ochna pulchra, Strychnos spp., and Securidaca longipedunculata.

The grasses are predominantly sweet and palatable and include Panicum maximum, Urochloa rhodesiensis, Digitaria spp., Schmidtia bulbosa, Andropogon amplectens, Cenchrus ciliaris, Setaria spp., Hyparrhenia spp., Brachiaria deflexa and Aristida meridionalis.

The Malelane hills display a tree and shrub community infused by species from the surrounding mixed combretum savanna woodland, but with such characteristic species as Adina microcephala var. galpinii, Piliostigma thonningii, Parinari curatellifolia ssp. mobola, Phyllogeiton zeyheri, Rauvolfia caffra, Olea africana, Phyllogeiton discolor, Ficus spp., Erythrina spp., Schotia brachypetala, Heteropyxis natalensis, Croton sylvaticus, Commiphora neglecta, Kirkia wilmsii, Pittosporum viridiflorum and Apodytes dimidiata. Distinctive trees growing on Numbi hill are Faurea saligna, Celtis kraussiana and Sterculia murex.

The forest-clad clopes and glades of the mountainous areas of the Park are favourite haunts of bush-pig, bush-buck, kudu, nyala (in the north) and grey duiker. The Malelane hills constitute an important habitat of mountain reedbuck and the well-wooded kloofs of Numbi hill afford the last permanent sanctuary to Natal or red duiker in the Park. Wild dog more often than not return yearly to these mountainous areas to give birth and rear their young. (iii) Riparian forest.

A narrow belt of closed forest along the banks of nearly all permanent and semi-permanent streams throughout the Park. Many fine, evergreen and deciduous trees are included in this community such as Acacia albida, Acacia robusta, Croton megalobotrys, Bridelia micrantha, Diospyros mespiliformis, Ekebergia meyeri, Garcinia livingstonei, Acacia xanthophloea, Ficus spp., Kigelia pinnata, Mimusops zeyheri, Pseudocadia zambesiaca, Adina microcephala var. galpinii, Combretum imberbe, Schotia brachypetala, Strychnos stuhlmannii, Syzygium guineense, Syzygium cordatum, Trichilia roka and Trema guineensis. Where they are protected from fire, palms - Hyphaene crinita and Phoenix reclinata grow to graceful size along the river banks.

The shrub stratum consists of species such as Combretum erythrophyllum, Ficus capreaefolia, Grewia spp., Euclea spp., Kraussia schlechteri, Salix spp., Azima tetracantha, Anisotes sessiliflorus and Cardiogyne africana.

Grasses are mostly shade-loving, and Panicum deustum, Panicum maximum, Setaria chevalieri, Cynodon dactylon and Oplismenus hirtellus are commonly found.

The dense reed beds (Phragmites communis) along the river banks and on the islands are inhabited by cane rats, otters and water mongooses and 
also afford shelter and food to many other species during the dry season. The reed islands are favourite breeding sites of lions.

The riparian forest proper is the almost exclusive habitat of bushbuck and a favourite haunt of nyalas, but most other large mammalian species utilize it in some way or other during their daily or periodic drinking routines.

(iv) Dry deciduous forest.

Isolated patches of this type of forest cover the flat crown of many hills in the Punda Milia area, along the south bank of the Levubu, and the Lebombo between Pafuri and Malonga spring and north and south of the Olifants Gorge. The typical aspect is a closed stand of several strata with Androstachys johnsonii the dominant tree species. The latter is deciduous and with a wood of fantastic hardness and durability. Associated species are Acokanthera oppositifolia, Albizia tanganyikensis, Ficus smutsii, Croton pseudopulchellus, Wrightia natalensis, Atalaya alata, Gyrocarpus americanus and Euphorbia cooperi. Shrubs and climbers are Strophanthus kombe, Cissus quadrangularis, Ipomoea spp., Cyphostemma schlechteri, Euclea schimperi var. daphnoides, and Hippocratea sp. Ferns are common in the understory. Grass is generally discontinuous and include such species as Enteropogon simplex, Tetrapogon lenellus, Setaria pallide-fusca, Sporobolus panicoides, Oplismenus hirtellus, Cymbosetaria sagittifolia, Chrysopogon montanus and Leptocarydion vulpiastrum. The Androstachys forests in the Park are favourite retreats of bush pig, forest elephant shrews and crested guinea fowl but also receive periodic visits from elephant, kudu, nyala, bushbuck and Sharpe's steenbuck.

\section{(v) The Lebombo ridge.}

The skeletal soils of the Lebombo riolytic reef is covered by a characteristic vegetation which varies only slightly from north to south. Colophospermum mopane is an important constituent of the tree stratum in the zone above the Olifants River, and also extends southwards to within a few miles of the Pumbe sandveld. In the south Pterocarpus rotundifolius takes its place.

Associated trees, which are for the most part deciduous, are Boscia albitrunca, Combretum apiculatum, Entandrophragma caudatum, Afzelia cuanzensis, Adansonia digitata, Stadmannia sideroxylon, Acacia nigrescens, Acacia erubescens, Acacia gerrardii, Albizia harveyi, Albizia brevifolia, Euphorbia confinalis, Euphorbia cooperi, Lannea kirkii, Combretum gueinzii, Cassia abbreviata var. granitica, Sterculia rogersii, Acacia tortilis, Commiphora spp., and Terminalia phanerophlebia.

The more commonly occurring shrubs are Hymenodictyon parvifolium, Bridelia mollis, Acacia ataxacantha, Acacia schweinfurthii var. schweinfurthii, Gardenia resiniflua, Elephantorrhiza spp., Portulacaria afra, Bauhinia kirkii, Pterocarpus rotundifolius, Heeria insignis, Holmskioldia speciosa, Dombeya kirkii and Monodora junodii together with xerophytic species such as Adenium obesum var. multiflorum, Pachypodium saundersii, Adenia spinosa, Aloe spp., 
Euphorbia spp., Caraluma, Huernia and Stapelia spp., and Sansevieria and Vellozia spp.

The grasses are generally coarse and of a less palatable nature, and include Andropogon gayanus var. squamulatus, Bothriochloa insculpta, Digitaria pentzii var. stolonifera, Cymbopogon excavatus, Heteropogon contortus, Aristida spp., Themeda triandra, Danthoniopsis dinteri and Schizachyrium exile.

The Lebombo mountain range is the permanent habitat of many klipspringer, mountain reedbuck (south of the Nwanetzi poort), dassies (north of the Olifants Gorgel and Sharpe's steenbuck, but is also an important summer feeding ground of many species such as elephant, giraffe, kudu, wildebeest, zebra, waterbuck and impala.

(vi) The Pumbe sandveld.

This is a small extension of the Mocambique sandveld south of the Olifants River which penetrates the Lebombo plateau for a distance of some 2 miles along with the $24^{\circ} 15^{\prime}$ latitude. It covers an area of not more than 20 square miles but is important from a botanical viewpoint in that it exhibits some affinities to the Punda Milia sandveld of the north; which is unique for the area south of the Olifants River. Arboreal species common to both these ecological isolates are Afzelia cuanzensis, Pseudolachnostylis maprouneaefolia and Combretum mechowianum. Common associated trees in the Pumbe sandveld are Terminalia sericea, Sclerocarya birrea, Acacia nigrescens and Combretum apiculatum, with Heeria insignis prominent in the undergrowth. Indicator species in the shrub stratum are Salacia kraussii and Eugenia zeyheri, and amongst the grasses there are Alloteropsis cimicima, Urochloa stolonifera and Digitaria didactyla.

Although the Pumbe habitat does not give exclusive sanctuary to any specific large mammalian species, it is significant in respect of being the only spring hare habitat south of the Olifants River.

(vii) Dense thornbush thickets.

Extensive areas with heavy, petitic soils of poor drainage in the Kruger Park are covered by a vegetation which can only be described as thornbush thickets, although a scaiter of irees occur in all these confines. Typical examples of such thornbush thickets are the well-known Nwatimhiri bush, as well as that of Gomondwane, both traditional habitats of the black rhinoceros in bygone days. As the name implies, ihe vegetation consists predominantly of thorny varieties of which a few species such as Acacia nigrescens, Acacia tortilis and Acacia delagoensis reach tree status. The thorny undergrowth includes Capparis tomentosa, Carissa bispinosa, Dalbergia melanoxylon, Dichrostachys cinerea, Dichrostachys cinerea ssp. nyassana, Gymnosporia senega'ensis, Acacia grandicornuta, Acacia tortilis, Acacia nigrescens, Acacia delagoensis, Acacia nilotica var. kraussiana, Acacia borleae, Acacia senegal var. rostrata, Balanites australis, Ziziphus mucronata and Fagara humulis. 
Thornless forms often associated with this complex are Cassine aethiopica, Euclea spp., Grewia spp., Securinega virosa, Gardenia spatulifolia, Combretum imberbe, Albizia evansii, Albizia forbesii, Manilkara mochisia, Pappea capensis, Pseudocassine transvaalensis, Rhigozum zambesiacum, Spirostachys africana, Cordia gharaf, Schotia capitata, Boscia mossambicensis, Adenium swazicum (in the south) and A. obesum var. multiflorum.

Grasses are sparse and easily trampled out. The most common species include Sporobolus spp., Chloris gayana, Chloris myriostachya, Tetrapogon mossambicensis, Dactyloctenium geminatum, Aristida spp., Cynodon dactylon and Schmidtia bulbosa.

Elephant herds spend a considerable time in these thornbush thickets and other species such as buffalo, kudu, bushbuck (near rivers), giraffe, impala and warthog follow in their wake. Grey duiker are also very partial to this type of habitat and troops of baboons, banded mongoose and bush babies are a common sight. Of the carnivora leopards and lion particularly seem to favour such environs. Queleas utilize these thickets as breeding colonies.

(viii) Bush-clad rocky outcrops.

Apart from the mountainous areas already described the smaller rocky outcrops or koppies which form an integral part of the bushveld scene may be regarded as a habitat in its own right, and have a distinctive and peculiar vegetation which applies almost universally. Xerophytic species such as Adenium obesum var. multiflorum, Pachypodium saundersii, Aloe spp. and Myrothamnus flabellifolius are common. The most striking tree species growing on these koppies are Ficus soldonella and Ficus ingens, Ptaeroxylon obliquum, Cussonia spicata, Combretum woodii, Dombeya rotundifolia, Erythrina spp., Steganotaenia araliacea, Kirkia acuminata, Olax dissitiflora, Schrebera argyrotricha, and Galpinia transvaalica, with Croton spp., Iboza riparia, Pavetta edentula, Vangueria infausta, Vepris reflexa, Grewia monticola, Ochna pretoriensis, Urera tenax and Euphorbia tirucalli prominent in the shrub-stratum. Grasses include Rhynchelytrum setifolium, Aristida spp., Andropogon gayanus var. squamulatus, Digitaria spp., and Heteropogon contortus.

These koppies are the chosen habitats of klipspringer and dassies lin the area north of the Olifants River), the Natal red hare, the Namaqualand rock rat and often also of porcupines. Leopards are of common occurrence and predate on the large troops of baboons which seek the inaccessible rock ledges of many of these koppies to spend the night.

(ix) Grassland plains and 'dambos'.

There are no true grassland plains in the Kruger National Park which are comparable with the 'dambos' of Mocambique and the Rhodesias. This is doubly unfortunate, as these 'dambos' and their surrounding fringe of woodland are apparently the habitat of choice of many plains-loving species and here particularly of eland, roan antelope, tsessebe and ostriches.

The headwaters of the water-courses which drain the Babalala-flats as 
well as the Tende-flats of the northern district however, form an extensive neiwork of relatively wide, shallow and poorly drained grassy valleys, where trees and shrubs are more or less absent. The most typical example is the Shawu valley, which originates in the Lebombos and drains into the Tsende River. It simulates in most respects the typical 'dambo' or grassland plain of the north and east albeit on a much reduced scale, and is in fact one of the most outstanding tsessebe, roan, eland and wildebeest habitats of the northern district. Both the Hlamalala and Nwashitsumbe valleys are also excellent examples of this type of ecological environment, and portions bordering the banks of the Bubube River are somewhat similar in appearance. The Boye!a and Nkulumbene drainage systems have become somewhat overgrown with a scrub-form of Mlala-palm (Hyphaene crinita) but could be regarded also to fall in this category.

Trees are of rare occurrence in these grassland valleys and are primarily specimens of Acacia xanthophloea, Acacia polyacantha subsp. campylacantha, Lonchocarpus capassa and Combretum imberbe. Tree or scrub-forms of Hyphaene crinita are of common occurrence.

The grass covering of these valleys varies from tall, coarse varieties intermingled with sedges towards the lowest levels, where conditions ameliorate to marshiness during the wet season, to shorter and sparsely-scattered associations on the poorly drained alluvial soils towards the edges of the drainage system. Comonly recorded species are Sporobolus robustus, Sporobolus nitens, Sporobolus panicoides, Sporobolus schlechteri, Setaria woodii, Ischaemum brachyaterum, Bothriochloa glabra, Dactyloctenium aegypticum, Eragrostis spp., Chloris virgata, Sorghum versicolor, Sorghum verticilliflorum, Cynodon dactylon, Chloris pycnotrix, Dinebra retroflexa, Cenchrus ciliaris, Themeda triandra and Lintonia nutans, together with Cyperus spp., Vernonia spp., and Sesbania spp.

The taller grass patches along these valleys provide excellent cover for reedbuck, whereas the shorter and more palatable species are well grazed by roan antelope, tsessebe, wildebeest, eland and zebra.

(x) Mopani climax forest.

On the well-drained sandy soils between the Shisha and Mphongolo Rivers in the northern district and alluvial soils along the eastern bank of both rivers a true climax forest has developed which retains much of its pristine character. The factors responsible for this phenomenon are complex but the existence of a system of roads and natural barriers have contribuied in no small measure to prevent the penetration of devastating veld-fires, which had for many years swept uncontrolled into the Park from the Portuguese territory in ihe east during the dry season. Fires which did enter the forest belt was checked to a degree by the sparse grass cover which developed in the shade of the closed tree and shrub strata. When conditions were particularly unfavourable i.e. during the peak of the dry season and with a high following 